\title{
ENGLISH MATERIAL DEVELOPMENT BASED ON SCIENTIFIC APPROACH: A CONTENT ANALYSIS OF "WHEN ENGLISH RINGS A BELL" COURSE BOOK
}

\author{
Elok Putri Nimasari \\ Muhammadiyah University of Ponorogo \\ Jalan Budi Utomo, No. 10, Ponorogo, East Java, Indonesia \\ elokputrinimasari@gmail.com
}

\begin{abstract}
Government has launched the 2013 curriculum four years ago. It becomes one of interests to be investigated. Pros and cons have been raised toward this new implemented curriculum. In 2014, a revision of the 2013 curriculum course book entitled "When English Rings the Bell" had been done. A content analysis study is needed toward the implementation of the 2013 curriculum for the sake of material development. This study aims to investigate whether or not the revised of the 2013 curriculum course book entitled "When English Rings a Bell" is in line with the theory of scientific approach. This study used qualitative descriptive method to describe the results.
\end{abstract}

Keywords: content analysis, scientific approach, when English rings a bell

\begin{abstract}
Abstrak
Pemerintah telah meluncurkan kurikulum 2013 sejak empat tahun yang lalu. Hal ini menjadi menarik untuk diteliti lebih lanjut. Pro dan kontra telah muncul atas penerapan kurikulum baru ini. Pada tahun 2014, sebuah buku ajar Bahasa Inggris yang berdasar kurikulum 2013 berjudul "When English Rings the Bell" telah dipublikasikan. Dalam hal ini, analisis isi diperlukan untuk melihat implementasi kurikulum 2013 di dalam buku tersebut demi perbaikan dan perkembangan materi ajar. Penelitian ini bertujuan untuk menginvestigasi apakah kurikulum 2013 yang diacu dalam buku "When English Rings the Bell" sesuai dengan teori pendekatan saintifik. Penelitian ini memanfaatkan metode deskriptif kualitatif untuk menjabarkan hasil penelitian.
\end{abstract}

Kata kunci: Analisis isi, pendekatan saintifik, when English rings the bell

\section{Introduction}

The government has currently developed a new curriculum from KTSP (Kurikulum Tingkat Satuan Pendidikan) to the 2013 Curriculum. The development of moral values in any aspects and skills becomes the main goal of the 2013 curriculum (Kementrian Pendidikan dan Kebudayaan, 2013). If in the previous curriculum teacher- centered learning is used, nowadays the key of the 2013 curriculum is student-centered learning. Students are asked to develop an autonomous learning.

In achieving the goals of the 2013 Curriculum, the ministry applies scientific approach as the key of the curriculum (Minister of Education and Culture Regulation No. 65/2013). Therefore, a new 
material of English course book for Junior High School has been created based on the scientific approach entitled "When English Rings the Bell" (WERTB) course book (Government Regulation no. 71/2013). After a year of implementation, the government has revised the course book, from "When English Rings the Bell" (WERTB) to "When English Rings A Bell" (WERB).

Pros and cons have been raised toward the implementation of WERB course book. A content analysis is needed to conduct due to those dynamic discussions. The results will be beneficial to improve the quality of the course book. According to Cunningsworth (1995), analyzing the course book is necessary since it is important resources for (1) presenting language components, (2) activities, (3) stimulating ideas, (4) self-directed learning, and in some contexts, (5) used as a syllabus and a support for less experienced teachers. In line with Cunningsworth, Tomlinson (2003) states that the results of content analysis of the course book will have a direct impact on the teaching learning process. Moreover, it can help the publisher to develop the materials; help the teacher to select the course book; and be the references for further studies.

Consequently, for accurate result, there must be an appropriate approach to analyze course book. Since "When English Rings a Bell" is created under scientific approach, this approach will be used to study. Due to the limitation of time and competency of the researcher, there will be only one unit to be evaluated. This study aims to investigate whether or not the revised of the 2013 curriculum course book entitled "When English Rings a Bell" is in line with the theory of scientific approach. To achieve the aim, the following research question has been set as:

1. How are the content analyses of "When English Rings a Bell" course book based on scientific approach?
2. Do the activities of "When English Rings a Bell" correlate with the syllabus of grade VII?

\subsection{The Role of Course Books}

A course book is created to meet and support students' needs for the demand of educational purposes. Course books are best seen as a resource in achieving aims and objectives that have already been set in terms of learners need (Cunningsworth, 1995). An appropriate course book should cover required indicators of a lesson learned by the students. Cunningsworth (1995) has proposed some multiple roles of course books in ELT. Course books can be:

1. A resource for presentation spoken and written material.

2. A source of activities for learners practice and communicative interaction.

3. A reference source for learners on grammar, vocabulary, pronunciation, etc.

4. A source of stimulation and ideas for classroom language activities.

5. A syllabus where they reflect learning objectives which have already been determined.

6. A resource for self-directed learning or self-access work.

7. A support for less experienced teachers who have yet to gain in confidence.

Based on those roles, it can be seen that course books serve as a medium, not as the master of for both teachers and students. The use of course book will give direct impact for teaching learning process. Thus, careful selection is so important to reflect the aims, methods, and values of teaching program. The purposes of the course books should match as closely as possible to the aims of the teacher, and both should seek to meet the needs of the students to the best achievement. 


\subsection{Scientific approach}

Scientific approach is a key of the 2013 curriculum. This approach is used as the basic method to create all teaching procedures and materials. Basically, science means knowledge. According to Lindberg (2007), learning with scientific method means that the students get the knowledge through some processes in which allow them to present the mental and physical behaviors of scientists. They are supposed as scientists, raising a question, learning a practical, finding useful approach, and answering the question scientifically. Agreeing with Lindberg, Fauziati (2014) states that scientific approach is a way of teaching which has same procedures as science. In line with Lindberg and Fauziati, Priyana (2014) implies that scientific approach is a systematic approach to discover knowledge based on a set of rules that defines what is acceptable knowledge. Another definition comes from Suharyadi (2014). He states that a scientific approach is a body of techniques for investigating the phenomena, acquiring new knowledge, or correcting and integrating previous knowledge. From those definitions, it can be concluded that scientific approach is a way to get knowledge through some steps as scientists do. Moreover, there are some principles in scientific approach.

\subsection{Previous Studies}

Some previous studies related to content analysis of the 2013 curriculum course book have been conducted. Susanto (2014) in his study reported that textbook had completed the criteria of a good textbook based on McGrath and been appropriate applied in each curriculum, though both of them had significant level that could make the students not ready for implementing it. Meanwhile, Syaifudin (2014) argued that the 2013 book did not have enough reading text to support students' reading skill. Therefore, development reading material was done. Another study conducted by Aziz (2014) showed that the English textbook for the seventh grade students which was entitled "When English Rings a Bell" (WERB) did not have adequate the listening materials. Dewanti (2014) in her research also found that the song in the end of each chapter in "When English Rings a Bell" was not varied. In addition, Ariewibowo (2014) proposed that the results of the study were clearly and empirically showed that the course book entitled When English Rings the Bells did not support the students learning effectively in the class.

\section{Methods}

Scientific approach, however, is old and new. It is old because this approach has been used before the 2013 curriculum. It is implemented in science courses. On the other hand, it is new because scientific approach is such a new way of learning in EFL classroom especially in Indonesia. There are many different ideas related to the principles of scientific approach.

According to Handelsman (as cited in Fauziati, 2014) there are three major principles in scientific approach: (1) active learning: a process in which students are actively engaged in learning; (2) assessment: tools for measuring progress toward and achievement of the learning goals; (3) diversity: the breadth of differences that make each student unique, each cohort of students unique, and each teaching experience unique. McCollum (as cited in Fauziati, 2014) proposes four basic principles of scientific approach: (1) Raising the curiosity, by having questions of "how" and "why"; (2) Continuing with an observation to gather the data; (3) Analyzing the data from observation results; (4) Communicating the findings with other learners. McTighe (as cited in Fauziati, 2014) suggests three principles: (1) identify the goals of learning; (2) determine the learning process and the assessment for the students; (3) plan instructional strategies, procedures, materials, and activities. Priyana (2014) proposes six principles: (1) 
Conduct an observation through reading or listening a text; (2) raise some questions that cover the indicators of the lesson; (3) conduct experiments by watching videos, interviewing resource persons, and reading books; (4) associate the data to answer the questions; (5) communicate the results to other learners in the classroom; (6) create texts as practical learning from previous processes. Similar to Priyana, Fauziati (2014) states there are five principles. Those principles are same as Priyana's. Only the sixth principle is not included. Based on those descriptions, the principles proposed by Priyana seem to be the most beneficial. In addition, those are principles applied in the 2013 curriculum.

\subsection{Observing}

Related to language learning, observing means that students have to read a text, listen a recording material or watch a phenomenon which links with the topic given. Observation is necessary to make students know what they are going to learn. Hopefully, at the end of this activity, students have a list of items that they want to investigate such as text structure, expressions, grammatical rules, cultures of the language, etc.

\subsection{Questioning}

Having a list of items to be investigated, it is time for students to raise some questions based on those lists of items. The questions should cover all indicators stated in lesson plan or required skills. Moreover, students are asked to have temporary answers based on the knowledge they have. At the end of this activity, students have a list of questions and temporary answers.

\subsection{Experimenting}

Experimenting means collecting the data or having information to answer the questions. It can be collected through interviewing resources person such as teachers, native speakers, reading books, browsing websites, etc. Hopefully, at the end of this activity, the students have enough information to answer the questions.

\subsection{Associating}

Associating refers to analyzing. In this activity, students analyze the information or data to answer the questions. They can analyze whether or not the temporary answers they have are in line with the facts. Factual information, thus, can support their answers.

\subsection{Communicating}

Having findings and conclusion, sharing and communicating to the others are important. Through this activity, students are asked to give feedback and get benefits from others. The output of this activity is that the students have constructed the knowledge such as text structures, language features, grammatical rules, and cultures.

\subsection{Creating}

Sharing the constructed knowledge is not the end of learning process. The students have to practice their knowledge. Opportunities must be given as many as possible to develop their practical skills.

\section{The Analysis}

The data is chapter five of "When English Rings a Bell". The topic is entitled "How many pets do you have?". The aims of the chapter are also written there. Students are encouraged to be able to count things, animals, and name public places. There are two pictures, a student and a teacher where the teacher emphasizes on an interrogative sentence, "How many pets do you have?". Moreover, this cover leads the readers to suppose that there will be three different kinds to count: animals, things, and public places. The cover is in the figure 1 below. 


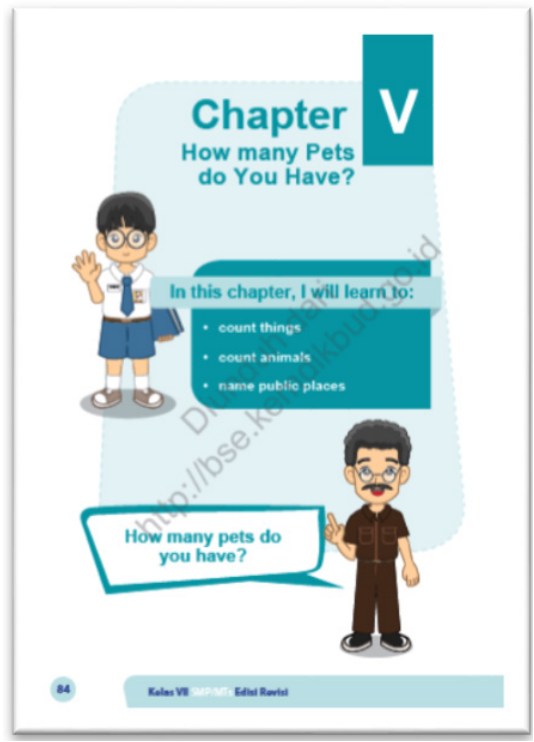

Figure 1. Cover of chapter V

Activity one and two are classified into observing activities. Activity one aims to make students understand by listening and pronouncing the words as teacher said. The words related to things that are familiar with students such as bags, rulers, pencils, dictionaries, etc. Activity two aims to encourage students by observing, mentioning, and writing the words provided. The vocabularies relate to things around students such as books, hats, rules, sharpener, etc.

These activities correlate with the syllabus. It is stated in observation stage that students have to listen and repeat many sentences such as mentioning the name of animals, things, and public places. But vocabularies provided are only about things around the students. It does not relate with the topic, "How many pets do you have". However, in scientific approach, observing activity lets students to read a text, listen a recording material, or watch a video. The text is the key in the application of scientific approach in language learning. Meanwhile, there is no text in activity one and two. There are no pictures of animals and public places. The activity is only emphasized on the difference between plural and singular by observing the pictures. Activity one and two are described as follows in figure 2 and figure 3 .

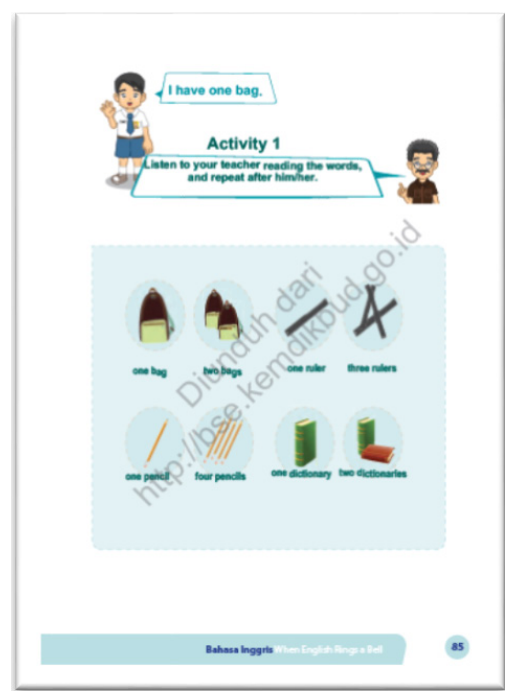

Figure 2. Activity 1 of chapter V 


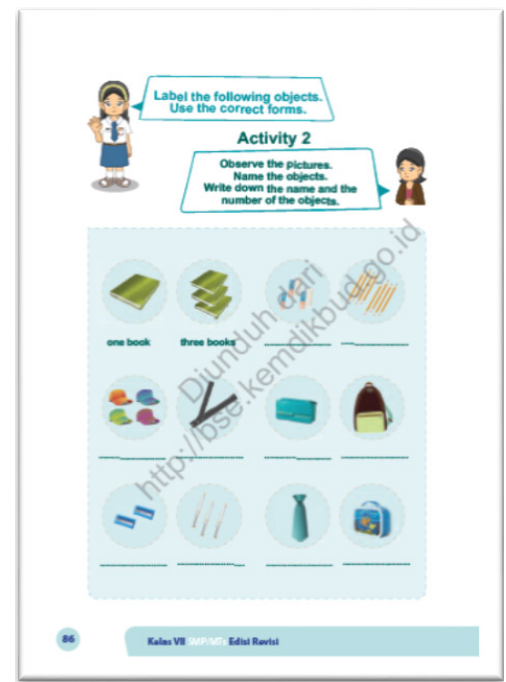

Figure 3. Activity 2 of chapter V

Questioning activities are applied in activity three until activity six. Students are asked to find some things in the living room, in the bedroom, and in the kitchen. They have to look the pictures provided and create sentences in pair. There are two examples stated in each activity. Those examples refer to the use of singular and plural in sentences. In activity six, students are required to describe the pictures individually. The vocabularies are about things at home such as a television, lamps, a sofa, a table, a stove, glasses, a bed, pillows, etc.

The activities have less correlated with the syllabus since there are stated that the students have to distinguish on how to create interrogative sentences about animals, things, and public places in English (L2) and in Indonesia (L1). According scientific approach, in the questioning stage, the students should have a list of questions that cover various language features such as generic structure, grammatical rules, and culture features. Related to the activity three until activity 6 , those features are less developed. Students are only asked to look the pictures and create sentences based on those pictures. They are not asked to create such questions. However, the pictures do not relate with the syllabus and the topic of the chapter. There are no animal and public places pictures. Figure 4-7 below represent activity three till activity six.

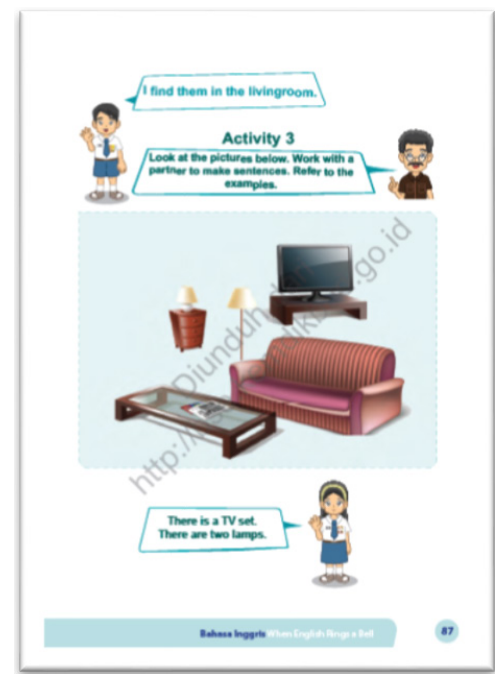

Figure 4. Activity 3 displays things in the livingroom 


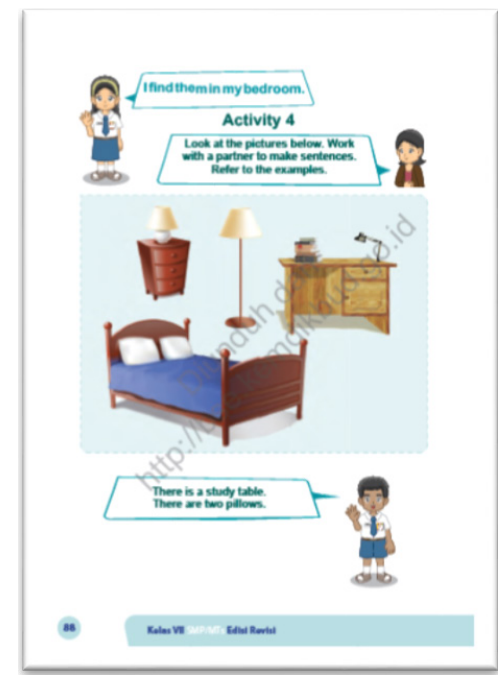

Figure 5. Activity 4 displays things in the bedroom

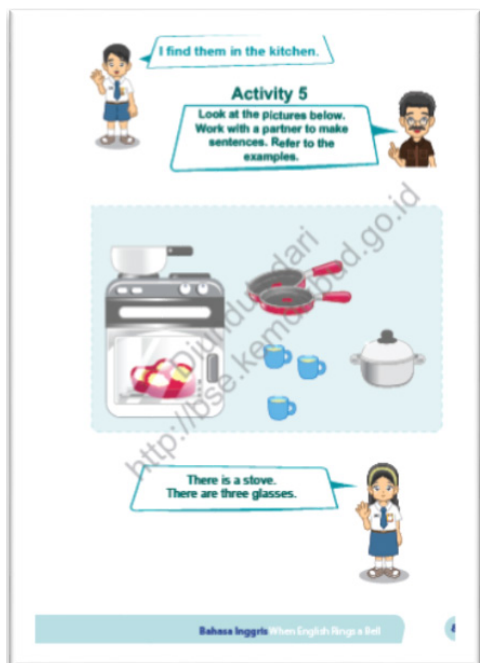

Figure 6. Activity 5 displays things in the kitchen

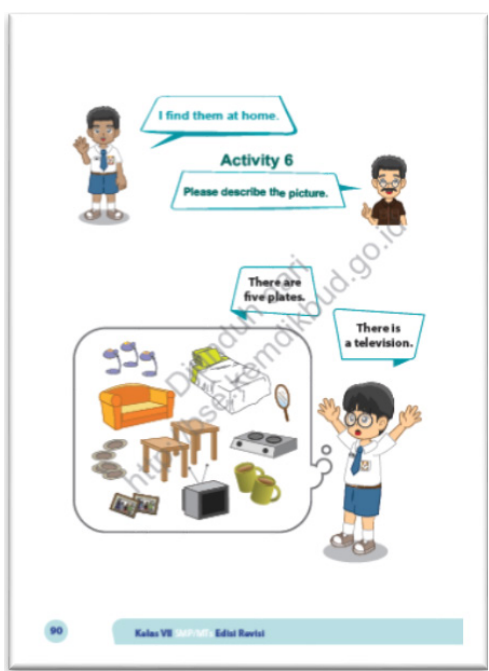

Figure 7. Activity 6 displays things at home

Next activities, activity seven until activities. These activities begin with activity nine belong to experimenting interrogative sentences, "How many pencils 
do you have?", "How many pencils does she have?", and "How many pencils does she have?". Thus, students are encouraged to write sentences in the table based on sentences stated. There are two examples for students in writing correct answers.

According to the principles of scientific approach, experimenting activities lead students to collect data or information to answer the formulated questions from questioning activities. Since students are not encouraged to create questions from the previous stage, experimenting activities provided in the book are not in line with the theory. However, it is stated in the syllabus that the activities should be done through role play or simulation context. There are not such simulation activities. Moreover, the vocabularies are only about things around students. Those vocabularies do not relate with the topic. Here are activities seven, eight, and nine.

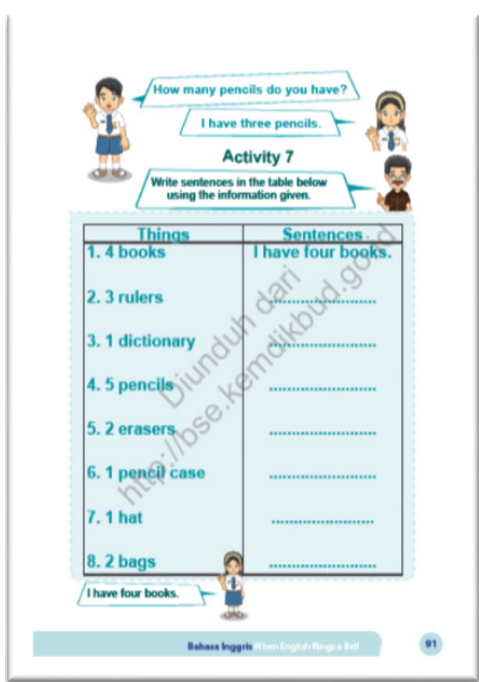

Figure 8. Activity 7 drills the students how to construct sentences

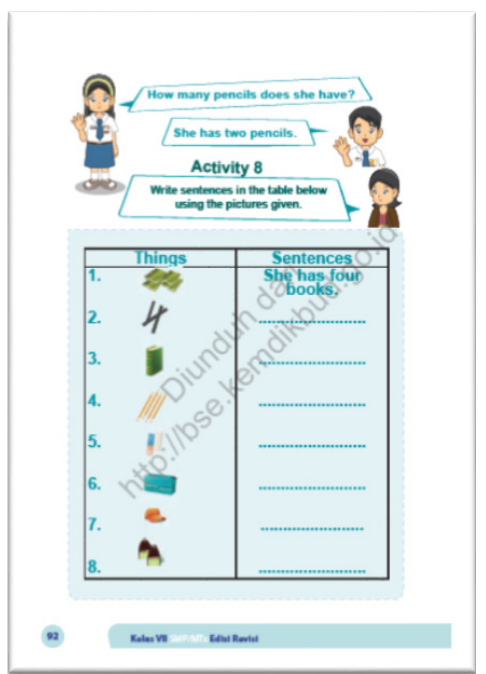

Figure 9. Activity 8 drills the students how to construct sentences 


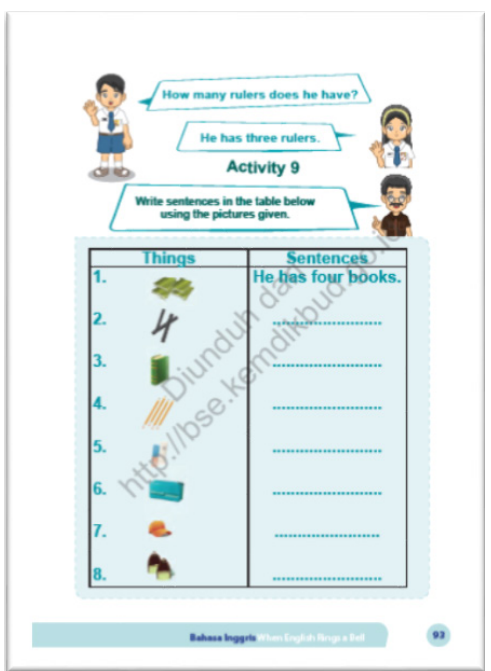

Figure 10. Activity 9 drills the students how to construct sentences

Activity ten and eleven are classified into observing activity. The students are asked to listen and repeat some words from the teacher. There is one example as a model for students. Drilling in this stage aims to make students realize the difference between plural and singular. The vocabularies are about animals such as cats, rabbits, dogs, and ducks.

The activities should continue to the next stage as scientific approach principles arrange. Activity ten and eleven do not provide such associating activities where they have to draw conclusion on how to differentiate between animals, public places, and various things inside and outside of the classroom; and how to differentiate the structures among positive, negative, and interrogative sentences. In addition, those activities do not correlate with the syllabus. It is stated in the syllabus that associating activity should be given after experimenting activity. As stated in the syllabus, the students have to analyze the difference of grammatical structures between English (L2) and Indonesia (L1). The following figures are activity ten and eleven.

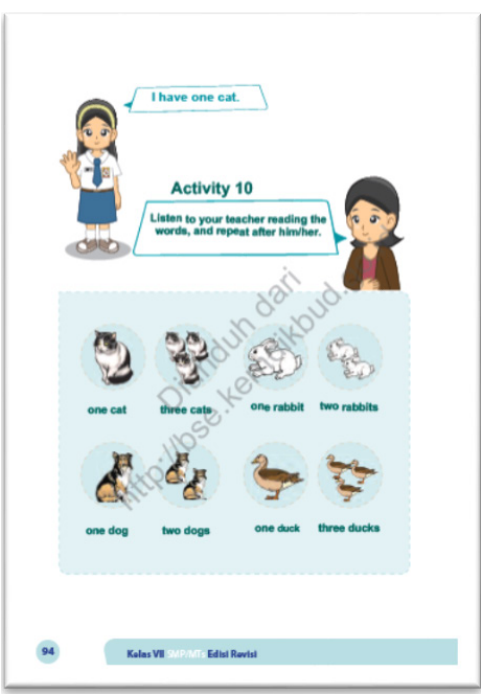

Figure 11. Activity 10 drills the students how to pronounce 


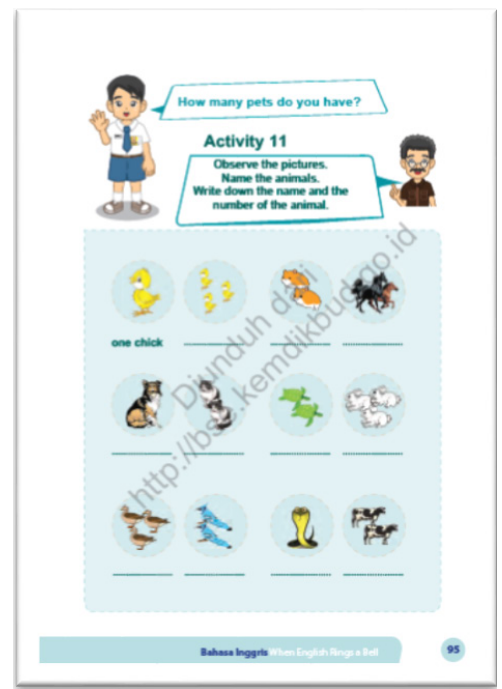

Figure 12. Activity 11 ask the students to observe the pictures

The next activity that will be analyzed is activity twelve. This activity belongs to questioning activity since students are asked to develop their curiosity of detail pictures. In this activity, students are asked to find and describe the pictures provided. The distinction between plural and singular is emphasized. This activity purposes to make students find the detail description of the pictures.

According to the principles of scientific approach, it is agreed that after observing activity, questioning activity should be followed. Since the previous activities, activity ten and eleven, are not followed the exact order of the principles, activity twelve becomes confusing for students. Although the vocabularies are about animal, this kind of activity should be in the similar stage to the first activity. In addition, questioning skill in this activity is less developed and less varied. Activity twelve is shown below.

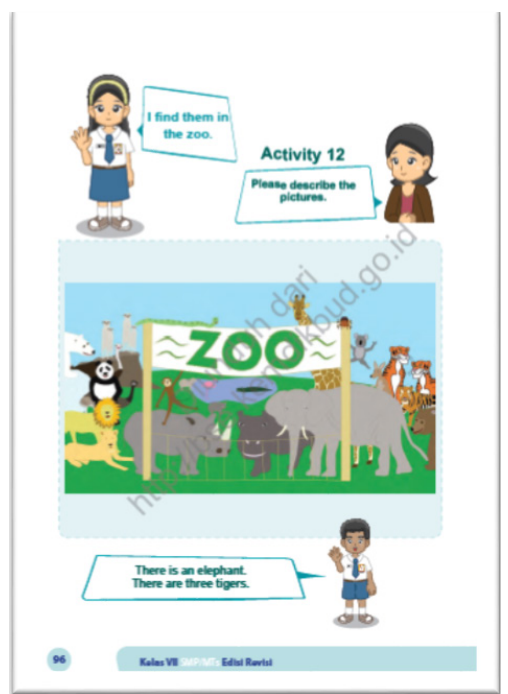

Figure 13. Activity 12 reflects observing stage

Activity thirteen belongs to observing activity. The aim of this activity is asking the students to observe what is described in the pictures. Students are encouraged to develop their critical thinking based on pictures provided. The pictures are about public places such as a garden, a supermarket, and a police station. 
According the principles of scientific to raise students' curiosity. The pictures approach, observation stage should cover provided are less motivated because they are various language features. Moreover, not real. The following is activity thirteen: authentic materials are supposed to use

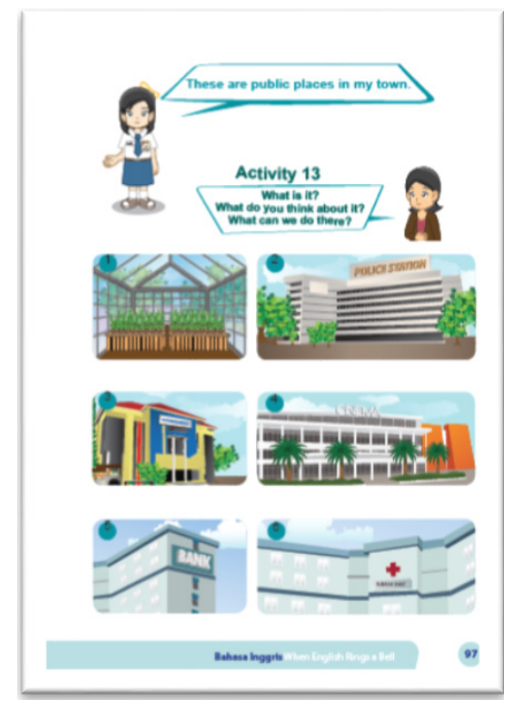

Figure 14. Activity 13 displays some pictures of public places

Moving to the last two activities, "Now I know..." and "My project", these activities are the end of learning process in chapter five. "Now I know" belongs to communicate activity due to its aim. This activity aims to ask students to share their new knowledge. On the other hand, "My project" reflects creating activity since students are asked to make such a project. The project is about list of vocabularies related to things around them, animals, and public places.

Based on the activities given, it relates to the principles of scientific approach. It is stated that at the end of learning process, there will be communicating stage and creating stage. In creating activity, students are given opportunities to practice their constructed knowledge. Meanwhile, in the syllabus, it is not stated that students have to create such a project. However, it does not matter because creating activity is included in the principles of scientific approach. The learning process of chapter five ends at the project activity. The following figures are "Now, I know.." and "My project" activity.

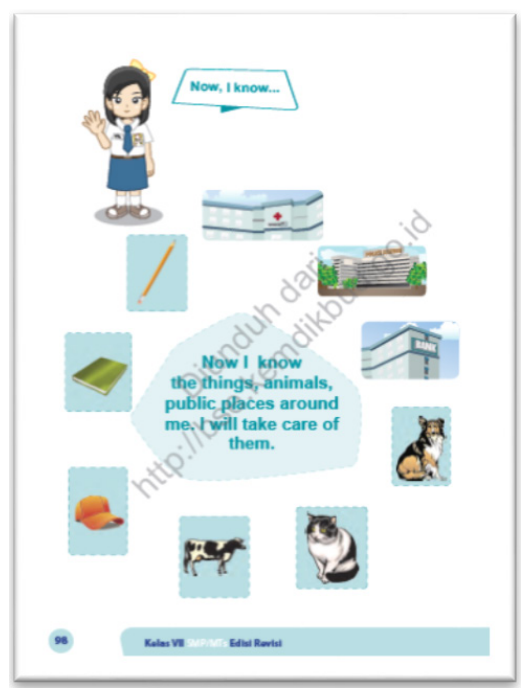

Figure 15. "Now I know" activity reflects to project activity 


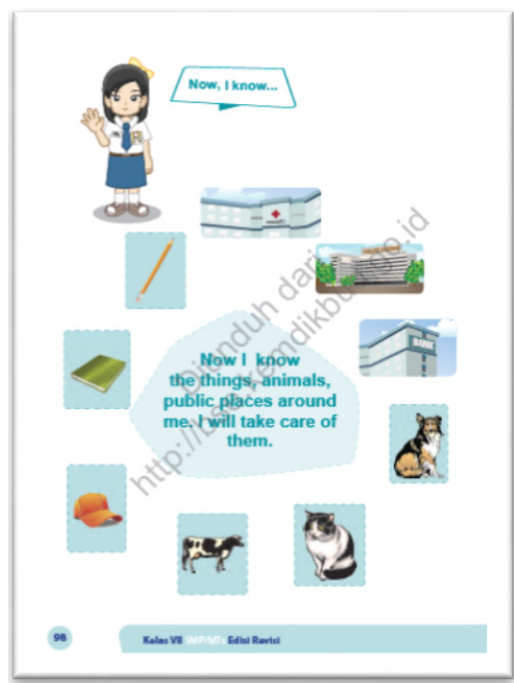

Figure 16. Mini dictionary reflects to project activity

\section{Discussion}

The analyses have been described. The results show that some activities, in chapter five of "When English Rings a Bell", are related to the principles of scientific approach and the rest do not. Although some of them relate to the order of scientific approach principles, activity one till activity nine, those do not completely follow the theory. They are less developed in terms of texts, language features, and grammatical rules. Students are only provided with a few examples. The examples are only in the form of sentences, not such kind of text or recording materials. They are not provided with appropriate worksheets and learning resources. Moreover, there is one missing stage. Associating stage is not given in chapter five. The activities given should be in the correct order of scientific approach principles proposed by Priyana (2014): observing, questioning, experimenting, associating, communicating, and creating.

Related to the syllabus of the 2013 curriculum for grade VII of junior high school, the activities do not ideally correlate with the steps stated in the syllabus. Some required context in the syllabus are missing and are not practically stated in the chapter five. Those are in terms of learning simulation, unbalanced vocabularies, contrastive grammatical rules analysis (between L2 and L1), and pronunciation.

Materials given do notcover thoseterms. The instructions given are inappropriate. Therefore, those make students confused on how to work with those activities. Since the topic is stated as "How many pets do you have?" there should be many vocabularies related to the animals. The aims are stated as count things, count animals, and name public places. But there are unbalanced vocabularies in amount. The pictures are not authentic. Authenticity is important to raise students' curiosity because it is close to their real world. In terms of grammatical rules, there are fewer examples on how students appeal between the structure in L1 and L2. Pronunciation practice is also not given. Students are only given opportunities by listening to the teacher and repeating the words. The activities are not supported with suitable recording materials. However, the syllabus has mentioned that pronunciation practice and contrastive analysis between L1 and L2 should be included in material. Based on the analyses and the findings above, it can be concluded that the activities applied "When English Rings a Bell" less correlate with the syllabus of grade VII. 


\section{Conclusion}

There are fifteen activities in the chapter five of "When English Rings a Bell". The analyses and discussion have been reviewed in the findings. To conclude this study, a number of points are presented:

1. Activity one and two are in line with the principles of scientific approach and the syllabus. But the activities do not achieve the aims of observing activity. The materials are less developed.

2. Activity three, four, five, and six are included in the questioning activities where questioning activity is the second principle of scientific approach but those less correlate with the syllabus. Although those activities are in included under the name of questioning activity, the activities do not encourage students to aim the purposes of questioning activity.

3. Activity seven, eight, and nine are considered as experimenting activities. However, those do not correlate in both scientific approach and the syllabus. The content developed to ask students in achieving the aims of experimenting activities.

4. Activity ten and activity eleven are included in observing activities. Those activities are not in line with scientific approach since associating stage should be done after experimenting activities. Thus, according to the syllabus, these activities should be done in the first activity. In addition, the features of the content are ambiguous.

5. Activity twelve is considered to involve in questioning activity. It does not relate with the order of scientific approach principles. Although it is included as questioning activity, however, inquiry skills are less developed. Therefore, it does not correlate with the syllabus since inquiry skill is emphasized there.

6. Activity thirteen is included in observing activity. It does not correlate for both the order of scientific approach and the syllabus. It should be done in the first activity of chapter five.

7. "Now I know..." activity is involved in communicating activity while "My Project..." is included in creating activity. These are the last activities of scientific approach. However, before giving those activities, students should be provided with the activities as the principles of scientific approach arranged.

The conclusions have been described. There are some pros and cons in the findings. The results will be so beneficial for the demand of content improvement. The revision is necessary since there are unequal content based on scientific approach and the syllabus. Thus, the content should be developed based on scientific approach principles. However, teacher roles in the use of the course book are important to meet the needs of the students.

\section{References}

Ariewibowo. (2014). An Evaluation Study: The Effectiviness of English Language Coursebook Entitled "When English Rings the Bell." In The 61st TEFLIN International Conference 2014 Proceedings. TEFLIN.

Aziz, M. (2014). Developing Listening Supplementary Materials for The Seventh Grade Students Based on 2013 Curriculum. In The 61st TEFLIN International Conference 2014 Proceedings. TEFLIN.

Cunningsworth, A. (1995). Choosing Your Coursebook. Oxford: Macmillan Heinemann.

Dewanti. (2014). Developing Song-Based Materials to Teach English for Grade VII Based on 2013 Curriculum. In The 61st TEFLIN International Conference 2014 Proceedings. TEFLIN. 
Fauziati, E. (2014). Methods of Teaching English As A Foreign Language (TEFL). Surakarta, Indonesia: Era PustakaUtama.

Kementrian Pendidikan dan Kebudayaan. (2013). Kerangka Dasar dan Struktur Kurikulum SMP/ Mts. Indonesia.

Lindberg, D. C. (2007). The Beginnings of Western Science: The European Scientific Tradition in Philosophical, Religious, and Institutional Context, Prehistory to A.D. 1450. The University of Chicago Press.

Priyana, J. (2014). Language Learning Activities. In Proceedings of The 61st TEFLIN International Conference. TEFLIN.

Suharyadi. (2014). EXPLORING “ SCIENTIFIC APPROACH ” IN ENGLISH.

Susanto, E. H. (2014). The Comparison between EFL Textbook Evaluations in 2013 Curriculum and KTSP Curriculum. In Proceedings of The 61st TEFLIN International Conference. TEFLIN.

Syaifudin, M. (2014). Developing Supplementary Reading Materials for The Seventh Grade Students of SMP Negeri Surakarta Based On 2013 Curriculum. In Proceedings of The 61st TEFLIN International Conference. TEFLIN.

Tomlinson, B. (2003). Developing Materials for Language Teaching. Cambridge University Press. 